\title{
Evaluation and Irony in Text in the Light of Speech Act Theory ${ }^{1}$
}

\author{
Wartościowanie i ironia w tekście w świetle teorii aktów mowy
}

\author{
Katarzyna KUKOWICZ-ŻARSKA ${ }^{2}$ \\ Ateneum-University in Gdansk
}

\begin{abstract}
This article focuses on the issue of valuation and discusses the role and textual properties of irony in the light of speech act theory. The research material used for the analysis comes from the novel by Philip Kerr "March Violets", which is a representative of the historical detective novel genre. The article does not aim to criticize the book's translations, but focuses on the message itself, which, through them, reaches the recipient and makes a specific impression on him/her. This specific impression, evoked by said speech acts and thoughtfully encoded in the text, is subject to the analysis here. Sociolinguistic assumptions have been adopted as the basis for these considerations, which seems to be justified in so far as language within such analytical framework can be treated as a binder across social groups, nations, communities, and may, therefore, play a significant role both in shaping them, shaping their collective beliefs, ideas, and cultural norms.

Keywords: evaluation, valuation, irony, axiology, sociolinguistics, text, speech act, speech act theory
\end{abstract}

\footnotetext{
${ }^{1}$ This paper is a translation of the article "Wartościowanie i ironia w tekście w świetle teorii aktów mowy" written by Katarzyna Kukowicz-Żarska, published in Forum Filologiczne Ateneum, (1(8)2020) on 2000, available online: https://doi.org/10.36575/2353-2912/1(8)2020.181 as part of activities for the research dissemination and internationalization of Polish science.

2 (C) https://orcid.org/0000-0002-6652-9068

Ateneum-University in Gdansk, Faculty of Modern Languages

k.kukowicz@ateneum.edu.pl
} 


\section{Streszczenie}

Niniejszy artykuł koncentruje się na zagadnieniu wartościowania, a także obecności i roli ironii w tekście i omawia je w świetle teorii aktów mowy. Materiał badawczy, służący do przeprowadzenia analiz na potrzeby artykułu, pozyskany został z powieści autorstwa Philipa Kerra „March Violets”, reprezentującej gatunek historical detective novel. Artykuł nie obiera sobie za cel krytyki dokonanych tłumaczeń, lecz skupia swoją uwagę na samym przekazie, który za ich pośrednictwem dociera do odbiorcy i wywiera na nim określone wrażenie. Owemu wrażeniu właśnie, wywołanemu poprzez przytoczone akty mowy i w sposób przemyślany zakodowanemu w tekście poświęcono część rozważań. Za podstawę owych rozważań przyjęto założenia socjolingwistyki, co wydaje się o tyle zasadne, iż język w ramach tak nakierowanych analiz traktowany być może jako spoiwo grup, narodów, społeczności i pełnić niebagatelną rolę zarówno w kształtowaniu ich samych, jak i kształtowaniu ich zbiorowych przekonań, wyobrażeń i norm kulturowych.

Słowa kluczowe: wartościowanie, ironia, aksjologia, socjolingwistyka, tekst, akt mowy, teoria aktów mowy

\section{Introduction}

The analysis in this paper focuses on the language of valuation as well as the role of textual irony in the light of speech act theory. As the grounds for my considerations, I take certain sociolinguistic assumptions, a step that proves justified in so far as language within such analytical framework can be treated as a binder among social groups, nations, communities, and may, therefore, play a significant role both in shaping them, shaping their collective beliefs, ideas, and cultural norms. According to Grabias (2019, p. 91), "sociolinguistics in its attempt to describe linguistic behaviour should aspire to discover a social communicative acts system"3 ${ }^{3}$ own translation - A.J. $]$. Therefore, the descriptive unit used for the analysis in this paper takes the form of Austin's conception of a speech act $^{5}$ (understood as action through language), which in a broad context constitutes part of a text. In this context, I also include the social nature of language, in acknowledgement that as a social construct

\footnotetext{
3 "Socjolingwistyka, opisując reguły zachowań językowych, winna dążyć do odkrycia systemu społecznych aktów komunikacji." (Grabias 2019, p. 91).

${ }^{4}$ All quotes were translated from Polish into English by Arkadiusz Janczyło [A.J.].

${ }^{5}$ I treat speech acts as a linguistic phenomenon, well-known in the literature, thus its thorough theoretical presentation proves superfluous here. With certain modifications for the purposes of the analysis, I take Austin's conception and its followers (Searle) as the grounds for my considerations. For more information on speech acts in this aspect see chapter "Jak działać słowami [How to Do Things with Words] (Austin, 1993, pp. 640-655) and Searle (1980), Lipczuk (2000), Zdunkiewicz (1993). Tryńska (2015) also presents an interesting take on this topic.
} 
language is simultaneously an entity that creates as well as conditions the existence of social groups (see Grabias 2019, p. 17). Further considerations, therefore, consist in the following statement:

In considering the "social nature of language" it is necessary to take into account consequences of such a dichotomous approach to the issue: language, being a construct of the society, constructs social life on its own. ${ }^{6}$ (Grabias 2019, p. 17)

This thought will reappear further in this paper, where the idea of a social group whose language "being a construct of the society, constructs social life on its own (ibid.)" is applied to German society in the National Socialism era; thus, a nation as a social construct, society at large, "understood as a brotherhood of blood (a biological community) rather than a community of ideas; socially conceptualised through the cultural metaphor of a great 'family' of all Germans."7 (Drozdowicz, 2010, p. 49) ${ }^{8}$.

As regards the concept of valuation and its correlation with the speech act theory in the context of the language of National Socialism ${ }^{9}$, I will restate one of my propositions from an earlier paper:

Reality is created through language, and since selected aspects of it are assigned different evaluative references, which are meant not only to reflect our attitude towards them, but frequently and implicitly force the recipient of a linguistic message to react mentally and/or physically in a way determined or desired by the sender, thus it should come as no surprise that the language of National Socialism is being examined here from the linguistic and sociocultural perspectives. ${ }^{10}$ (Kukowicz-Żarska, 2018, p. 61)

\footnotetext{
6 “W rozważaniach o „społecznym charakterze języka” trzeba mieć na uwadze konsekwencje wynikające z takiego właśnie, dychotomicznego, ujęcia problemu: język, będąc wytworem społeczeństwa, sam konstruuje życie społeczne." (Grabias 2019, p. 17).

7 (...) "identyfikowany nie tyle ze wspólnotą ideową, co ze swoistym braterstwem krwi (wspólnotą biologiczną), konceptualizowanym społecznie poprzez kulturową metaforę wielkiej „rodziny” wszystkich Niemców.” (Drozdowicz, 2010, p. 49).

${ }^{8}$ For more information about the German concept of nation and community (in the context of the Nazi Occult) see: Drozdowski (2010), and in the context valuation in language along the lines of national ideals: Kukowicz-Żarska (2018).

${ }^{9}$ For more information about the academic debate concerning the phenomenon of "the language of national socialism" see Kukowicz-Żarska (2018, pp. 65-66).

10 "Jako że wybranym elementom rzeczywistości kreowanej przy pomocy języka zwyczajowo przypisujemy oceny, które nie tylko mają odzwierciedlić nasz stosunek do nich, lecz także nierzadko w sposób implicytny mają zmusić odbiorcę komunikatu językowego do określonej i pożądanej przez emitenta reakcji mentalnej lub fizycznej, nie powinien dziwić fakt, iż język
} 
The research material under investigation here is taken from a novel by Philip Kerr called "March Violets", which is a representative of the historical detective novel genre ${ }^{11}$, or, as Andrzej Garlicki wrote in his review for the "Polityka" magazine: "an amalgamation of a classic detective novel with historical reporting, which has recently come into fashion"12. The original novel was written in English, and its first edition was published in 1989 by Viking Books in London. The translation into German was performed by Hans J. Schütz (1995) $)^{13}$, and into Polish by Ewa Fiszer (2009) ${ }^{14}$.

This paper does not aim to criticize the book's translations, but focuses on the message itself, which, through them, reaches the recipient making a specific impression on them. This specific impression thoughtfully encoded in the text is evoked by said speech acts which here are claimed to be purposeful. Although translation choices the translator made prove fascinating and definitely deserve more attention, this article does not focus on the mere creative process which leads to a desired final effect by way of the published translation, but rather on said final and tangible effect itself as well as its power. It is precisely such thoughtful and meticulously selected phrases that intend not only to reflect the writer's idea, but also, or perhaps above all, when translated into a given foreign language their role is to reach the native reader with a message and evoke a certain mental reaction - directly or indirectly influence their reception of the content, perception, and perhaps even change their attitude.

narodowego socjalizmu badany jest tu w perspektywie językoznawczej i socjokulturowej." (Kukowicz-Żarska, 2018, p. 61).

11 Also referred to as historical mystery or historical whodunit as a subgenre, representing a compilation of two literary genres: historical fiction and mystery fiction.

12 (...) "modnym ostatnio połączeniem klasycznej powieści kryminalnej z historycznym reportażem” (Garlicki, 2009).

13 The first German edition of "March Violets" by Phillip Kerr translated by Hans J. Schütz was published in 1995 by Rowohlt Publishing House in Reinbek. In my analysis of "March Violets" I take from a special German edition of the novel (Sonderausgabe) from 2007 which came out as a collective edition called "Die Berlin-Trilogie", published by the Rowohlt publishing house, Reinbek 2007 and contained first 3 volumes in a series Sprawa dla Bernharda Gunthera [A Case for Bernhard Gunther] (Ein Fall für Bernhard Gunther): "March Violet" (Feuer in Berlin), "The pale criminal" (Im Sog der dunklen Mächte) and "A German Requiem" (Alte Freunde, neue Feinde).

${ }^{14}$ The first Polish edition of the novel translated by Ewa Fiszer was published only in 2009 by the Red Horse publishing house in Lublin. For the analysis in this paper I take the 2nd, corrected edition of "March Violets" from 2014 published by W.A.B. in Warsaw, also translated by Ewa Fiszer. 


\section{Speech acts in the light of the language of National Socialism and sociolinguistic research}

Grabias (2019, pp. 35-36) cites the speech acts conception within sociolinguistic research after Lubas ${ }^{15}$, who modified the structuralist juxtaposition of langue and parole and applied it to define speech acts as "concretised language realisations where an individual partially uses their competence as a member of a given society, as a member of a given community and partially their own individual competence as one of representatives of human kind"16. Grabias (ibid.) contests as follows:

Thus in speech acts human beings are subject to linguistic behaviour rules relevant to the social group they belong to, and shape such behaviour themselves in a way which is most appropriate to their individual psychological qualities. ${ }^{17}$

Grabias simultaneously poses a question, fundamental in the context of linguistic communication theory: "How far is an individual subject to social rules of text construction, and how far do they create such texts?"18. This question is directly connected with the assumption made at the beginning of the paper.

Since every speech act by definition changes the reality in a way, modifies one of its aspects (see Lipczuk 2000, p. 173), then actually every phrase under analysis here presents an intervention into the recipient's mind, therefore, in the context of a perlocutionary effect, as Austin explains, it creates specific changes "in listeners' spheres of emotions, thoughts or actions"19 (Austin, 1993, p. 646). Evidently, recognising the sender's intention conditions a speech act's influence and its power as well as is a key element in message

15 Grabias quotes Lubaś's sociolinguistic conceptions presented in his book called Społeczne uwarunkowania współczesnej polszczyzny [Social Conditioning of Contemporary Polish] (1979) as well as in numerous articles published in the "Socjolingwistyka" journal.

16 (...) "ukonkretnione realizacje językowe, w których jednostka zużywa częściowo swoje kompetencje jako członek danego społeczeństwa, jako członek danej grupy i częściowo swoje kompetencje indywidualne jako jeden z przedstawicieli gatunku ludzkiego" (Grabias, 2019, pp. 35-36).

17 "Zatem w aktach mowy człowiek podlega regułom zachowań językowych właściwych grupie społecznej, do której należy, i sam zachowania te kształtuje w sposób odpowiadający jego indywidualnym właściwościom psychicznym." (ibid.)

18 "Na ile jednostka podlega społecznym regułom budowy tekstów, a na ile teksty te kreuje?" (ibid.)

${ }^{19}$ (...) “w sferze uczuć, myśli lub działań słuchaczy” (Austin, 1993, p. 646). 
interpretation, as speech acts are subject to certain conventions, "basic conditions must be fulfilled for a given statement to be effective" ${ }^{20}$ (Trysińska, 2015, p. 64). Apart from an individualised way of receiving a message, its cultural aspect must also be appreciated, which plays an extraordinary role in text's reception and interpretation, in particular, a text such as analysed in this paper:

For every speech act is a located structure, i.e. is connected with speakers' cultural and personal events. Ultimately, it is not only grammar, but also social and personal events of communication process participants that have bearing on the meaning and internal structure of a statement. ${ }^{21}$ (Grabias, 2019, p. 39)

With reference to the issue of valuation in question Grunberger (1989) can be quoted, who illustrates in a truly sophisticated way the relation between the era of National Socialism presented in the book and language:

Nazis plundered and contaminated the German language with the same merciless conscientiousness as they treated other human and material resources; they deprived it of any grace, subtlety, diversity. They used words not as bridges leading to recipients' minds, but as harpoons impaled into the delicate matter of their sub-consciousness. They reduced various applications of speech e.g. communication, argumentation, advocating ideas, monologues, prayers or spells - to one and only function: magical. ${ }^{22}$ (Grunberger, 1987, p. 387)

Despite the whole weight that the German period of National Socialism carries, Philip Kerr, i.e. the author of "March Violets", attempts to use words as bridges to the recipient's minds in order to reach the delicate matter of their subconsciousness and confront it in some sublime, yet deliberate, way. It is precisely for this purpose that he employs irony as a speech stylistic element

20 (...) "muszą zostać spełnione warunki podstawowe, aby dana wypowiedź była skuteczna" (Trysińska, 2015, p. 64).

21 “Każdy akt mowy jest bowiem „strukturą usytuowaną”, to znaczy powiązaną z kulturowymi i osobistymi zdarzeniami mówiących. Ostatecznie więc nie tylko gramatyka, lecz także społeczne i osobiste zdarzenia uczestników komunikacji decydują o znaczeniu i wewnętrznej budowie wypowiedzi." (Grabias, 2019, p. 39)

22 "Naziści splądrowali i zanieczyścili język niemiecki z tą samą bezlitosną sumiennością, z jaką traktowali inne zasoby ludzkie i materialne; pozbawili go wszelkiego wdzięku, subtelności, różnorodności. Używali słów nie jako pomostów do umysłu rozmówcy, ale jako harpunów wbijanych w delikatnąmaterię jego podświadomości. Rozmaite użycia mowy - jako komunikacji, argumentacji, obrony idei, monologu, modlitwy czy zaklęcia - zredukowali do jednej jedynej funkcji: magicznej." (Grunberger, 1987, p. 387) 
and a certain guarantee of message adequacy, as well as presents valuation, which determines his faith in the effectiveness of this particular narration style.

\section{March Violets as an object and subject of valuation}

What seems particularly interesting in the context of the analysis here is the juxtaposition of specific speech acts in German - as a language of the reality described in the novel - and their equivalents in Polish, as a language whose native speakers perceive this discourse as especially significant and still alive, as well as the relation between the text's intentionality and acceptability. If intentionality as one of text's criteria refers to the sender (here: both the author of the original and indirectly the translator) then the acceptability and message of said text comes from the recipient's position - i.e. the reception of given speech acts within the recipient's circle of the projected target group. With reference to the analyses in this paper, I treat every recipient of the text who is also a user of a given language as a member of the target group - in particular, however, a native language user for reasons of additional sociocultural elements in the analysed speech acts and their influence on the reception of a given linguistic action. Interestingly, the translation of particular phrases into German turned out mostly utterly faithful and proximate in the structure and effect to the original language, which might mean that Philip Kerr, as the author of the original version, showed in the eyes of the German translator fluency in describing the linguistic reality, and also managed to grasp the convention so characteristic of the contemporary German usage. Although formal similarities do not seem surprising for reasons of kinship between the two languages, it seems intriguing that both languages share a common convention to convey ironic or valuation effects, e.g. in descriptions of situations and places, or even the protagonist's language.

As the note from the publisher accompanying the first Polish edition informs, "March Violets" (2009) "is a novel which opens a series of black detective stories about Bernie Gunther and presents to the reader an extraordinary image of the Third Reich at the birth of her power and demise"23. The action is set in Berlin in 1936, a year of the summer Olympics taking place in Nazi Germany's capital. It is the image of these

23 (...) "to powieść otwierająca serię czarnych kryminałów o Bernim Guntherze, ukazujących czytelnikowi niezwykły obraz III Rzeszy u narodzin jej potęgi i po jej upadku” (Kerr, 2009: "March Violets"). 
Olympics - both their preparation and particular moments as well as a premonition what was going to come next - that plays a significant role in the novel, underlying a series of ironic comments which employ various linguistic means of valuation (such as comparisons, euphemisms or metaphors). As I pointed out in my earlier paper on valuation and "the strength of word and the power of expression" - "siły słowa i mocy wyrazu" (Kukowicz-Żarska, 2019), language of valuation constitutes an extraordinary weaponry in the emotional language of National Socialism.

While discussing the issues of valuation and irony in the text under analysis here it is worth focusing first of all on the dimension of the novel's title. The Polish title "Marcowe fiołki" is fully equivalent to the original, "March Violets"; however, in German the original title is replaced with an altogether different one: "Feuer in Berlin". If one looks at the title as a speech act of a characteristic function, an attempt is called for to discuss this material interference in such a representative element of the text. The German translation of the novel seems faithful towards the original, therefore such a significant interference in the title comes as a surprise, especially so as the title is not only a preview, an intriguing introduction, but is also a signpost pointing the reader in the direction that the book is going to meander as they read along. The whole novel was based on a purposeful wordplay concerning the so-called March violets; it implied a typical social group that they referred to, and whose image was established in the original and kept in the Polish translation. With this image missing in the German title it fails to provide the direct reference to the characters who are called March violets, and seems to introduce the reader to the book by referring to the event of setting fire to the Reichstag in $1933^{24}$. It can be assumed that in the German culture and language (the term Reichstagsbrand connotes negatively) the event has left a distinct imprint and displays such a tangible evaluative force that in the translation it was accepted as a fore-rider to the events presented in the book. The title itself can be understood as a performative speech act - it does not display a purely informative function and is not subject to truth conditions in terms of logic. The context implied in the title plays a main role here, and the force of the titular phrase varies from language to language. In fact, the term March violets has its equivalent representation in German:

\footnotetext{
24 The fire of the Reich parliament in Berlin (German Reichstagsgebäude) took place at night of 27/28 February 1933 and became a pretext for Hitler to sort his inconvenient opposition, to introduce state of emergency in the whole country and became a symbol that was heavily abused in political struggle.
} 
Märzveilchen; however, the term which occurs much more frequently in this meaning is Märzgefallene (Kerr 2007, pp. 16, 62, 85, 131, 145). Märzgefallene is an ironic and mocking term of a strong emotional underpinning; it displays unambiguously negative evaluative qualities, both at that time and nowadays, and is applied pejoratively to opportunists who joined the NSDAP (the National Socialist German Workers' Party) following the Reichstag election of 5 March 1933 (see Schmitz-Berning, 2000, p. 399). Thus, this name is used to refer to new party members who applied to join the national socialist party following its Reichstag victory only, and who were accused of opportunism by the socalled "old fighters"; they were disparaged, treated with reserve and distrust. As the will to join the party became so common, the purity of the candidates' intention was doubted. This sheep gather resulted from, on the one hand, a wider opportunity given to those who had been banned from joining the party, and on the other hand, many careerists appeared who wanted to transcend their social status as well as ordinary apostates who were afraid that their professional situation would decrease should they fail to become NSDAP members. An explanation for this socio-cultural phenomenon came by way of a footnote in the Polish translation ${ }^{25}$, yet in the German version this is not mentioned at all. Interestingly, the term Märzgefallene was initially applied to the victims of the March Revolution of 1848 who died in Berlin during street fights with the Prussian army (see Schmitz-Berning, 2000, p. 399).

What is striking from the point of view of the analysis here is a joking mini-dialogue - a short exchange between two anonymous men. The joke comes from the magazine "Das Schwarze Korps", dated November $1935^{26}$ and relates directly to the novel's title, or even the characters and the attitude of the March violets themselves:

Mężczyzna pierwszy: My, weterani, jesteśmy kompletnie lekceważeni. Popatrz na te "marcowe fiołki", wszystko jest dla nich.

\footnotetext{
25 The additional note in the Polish translation, made probably by the publisher since no implication is provided that it was made by the translator, Ewa Fiszer, says: „Tytułowymi 'marcowymi fiołkami' nazywano kpiąco karierowiczów masowo wstępujących do partii hitlerowskiej od marca 1933, kiedy to NSDAP zdobyła przeszło 44\% głosów w wyborach parlamentarnych i dzięki czemu Hitler przejął pełnię władzy w Niemczech" ["The titular 'March violets' is a term used mockingly to refer to careerists who joined Hitler's party en masse as of March 1930, when the NSDAP won over 44\% votes in the parliamentary election, and as a result of which Hitler took over all power in Germany"] (Kerr, 2007, p. 7).

26 "Das Schwarze Korps" is a title of an official Nazi newspaper - a propaganda tool of the Schutzstaffel (SS) organisation - which came out from 1935 to 1945 and reached printed in huge numbers of free copies.
} 
Mężczyzna drugi: Święta racja! Gdyby Führer później wstąpił do partii, zaszedłby dużo dalej. (Kerr, 2014, p. 7)

FIRST MAN:

- gloss: We, veterans, are completely ignored. Take a look at these "March violets", everything is for them. [own translation - A.J.]

- Have you noticed how the March Violets have managed to completely overtake Party veterans like you and me? (Kerr, 1989)

SECOND MAN:

- gloss: Absolutely right! If Führer had joined the party later, he would have achieved much more. [own translation - A.J.]

- You're right. Perhaps if Hitler had also waited a little before climbing on to the Nazi bandwagon he'd have become Führer quicker too. (Kerr, 1989)

In the Polish version the first man's statement concentrates on complaining in the first speech act and anger/grudge expression in the second. Personal pronoun "we" is used here, which becomes the evident subject of the sentence, and thus depicts a group of complainers. As a result, what is pointed out is the us $\neq$ them dichotomy so characteristic in the language of National Socialism (although not only there). "We" (the good and worthy) in conjunction with a positively evaluative lexical unit of "veterans" create an image of a specific social group, establishing a collective - a social-national community, simultaneously implying proper recognition and splendour. The group, however, does not experience the recognition despite the fact that during the National-Socialism era lexeme veterans was a truly significant element in the construction of the national ethos. The speech act, therefore, takes on an expressive character: Veterans feel ignored - in fact an explicit phrase is used: "completely ignored - and the cause behind this situation is thought to be "March violets" (the other, the bad, of little worth). The fact that a given group is seen as the culprit blamed for such a state of affairs constitutes an even bigger insult as it was the March violets, opportunists, unworthy individuals, even the weird, who reap all the benefits - which makes the juxtaposition of the two speech acts even more powerful. Both speech acts have a powerful emotional dimension, they uncover feelings and apply analogy and contrast to evoke in the recipient the impression of instability to the social relations of the time. The imperative structure gives the second speech act a directive character, a perlocutionary force - the modern reader would also have an impression that March violets are an unworthy group and unfairly rewarded, and as a result perceive it in the negative light. In reply, 
the interlocutor expresses approval for previous statements - unequivocally and explicitly, and employing exclamation as a means of expression to this end. Then, he implicitly comments the social attitude to March violets claiming that "If Führer had joined the party later, he would have achieved much more" ("Gdyby Führer później wstąpił do partii, zaszedłby dużo dalej”), which displays the whole emotional view on the situation - had he been a March violet, his career would have come to him itself and to a much greater effect. Additionally, this humour-based speech act seems to imply that Hitler could have indeed gone much further and achieved considerably more than he actually did at the time in that surrounding reality. What is interesting, the speech acts in the fragment just discussed seem to have double force: on the one hand, they relate to the relationship between the sender and the recipient through the dialogue between them; on the other hand, they relate to the relationship between the sender and the recipient from the author-textreader perspective. At this point, it is worth referring to the relations that are formed on this basis, taking into account the valuation that occurs at the same time: first, then, an emotion appears as an impulse for the production of a text, then valuation comes as a means of influence, then the text itself is produced as a means of expression, eventually arriving at the reception of the text being a result of the production process and, finally, action takes place as a result of the text's reception provoked by emotion. The irony contained in the quoted speech act is therefore intended to express emotions that, on the one hand, contribute to the creation of the text, and on the other, will cause an appropriate action in the recipient - the mental reaction and the laughter that directly follows it.

Grunberger writes that "anti-Nazi humour constitutes both a minimal expression of resistance (or at least disapproval) and a form of therapy."27 (1987, p. 395). In the German text, the latter speech act containing an ironic supposition, which is the source of humour here, differs significantly from the Polish version; here we have the statement that if Hitler had waited a little longer before joining the National Socialists, he might have become a Führer sooner. Thus, this speech act does not imply anything more than what Hitler finally managed to achieve, i.e. the actual state of affairs:

Erster Mann: Ist dir aufgefallen, wie die Märzgefallenen es geschafft haben, alte Parteigenossen wie dich und mich hinter sich zu lassen?

27 (...) "humor antynazistowski był zarówno minimalnym wyrazem oporu (albo przynajmniej dezaprobaty), jak i formą terapii.” (Grunberger, 1987, p. 395). 
Zweiter Mann: Du hast recht. Hätte Hitler auch noch ein bißchen gewartet, ehe er zu den Nationalsozialisten ging, wäre er vielleicht schneller Führer geworden. (Kerr, 2007, p. 11)

The first man's statement also revealed an expressive nature of this speech act, but what is emphasised most of all here is the fact that it was March violets who performed specific actions that made the "old party comrades" left out, and this begs a question whether the interlocutor noticed it. The sense remains the same, but the question provokes an answer, which the former interlocutor takes as confirmation.

\section{Irony as an individual's weapon in battle against the system}

The novel contains two types of sender whose language is of particular interest in this article: on the one hand, it is the protagonist himself - Bernhard (Bernie) Gunther, a representative of the German National Socialist era society, and on the other hand, there are others like him - those who share a similar perception of reality, a similar attitude towards the world in which they live. Thus, the aforementioned social group whose language is subject to analysis here contains in the nation as a social construct in a broader context, as well as the protagonist himself being simultaneously a member of that nation, and at the same time a person in opposition to the majority of the society. Bernie Gunther is an archetypal character, presenting certain patterns of behaviour, along with norms and values commonly regarded as desirable, which makes him slightly over-idealized in the context of the period in question and quite predictable in action and words, but also displaying a considerable potential for linguistic analyses.

Irony as one of linguistic means of valuation constitutes a weapon for the protagonist in his battle against the system. Being so characteristic for the genre, he is in possession of a whole array of personality qualities and represents the patterns of behaviour which are characteristic for this type of representative of the social group. Bernhard Gunther is a man in the prime of life, a former criminal police officer, and now a private detective, who uses, often excessively, stimulants typical of his time - he willingly reaches for cigarettes, alcohol, and does not avoid the company of "ladies of the night".

Bernie Gunther presents a full range of characterological features expected of this type of character: is cynical, intelligent, funny, adamantand brave - although his bravery often borders on recklessness. However, what distinguishes this individual among all others in the novel is indeed 
the language he uses. A language that is sharp, acrimonious, mocking. Combined with a wry sense of humour, cutting remarks and sarcastic expression it finally makes for an effect whereby the character comes across as colourful, whose language actually deserves special attention. Gunther displays a speech manner so characteristic for Germany's capital, so-called Berliner Schnauze, i.e. a blunt way of speaking, saying everything "that comes to mind", plainly, with no regard as to how his words might be received. In the context of the times he lived and the role he had to play, it is the sarcasm and wry humour that allow him to survive through difficult times and constitute a kind of shield that protects him from the gloomy reality. With his characteristic subtlety he states:

Przyjmuję zlecenia dotyczące śledztw w sprawach ubezpieczeniowych, pilnuję ślubnych upominków i staram się odnaleźć osoby zaginione. Tak, odkąd nastał narodowy socjalizm, w tej dziedzinie bardzo zwiększyło się zapotrzebowanie na moje usługi. [...] Cóż, wszyscy skorzystaliśmy na objęciu władzy przez nazistów. Prawdziwe z nas „marcowe fiołki”. (Kerr, 2014, p. 12)

Ich arbeite für Versicherungen, bewache Hochzeitsgeschenke und suche vermißte Personen - solche, von deren Verschwinden die Polizei noch nichts weiß, aber auch andere, deren Verschwinden gemeldet ist. Ja, das ist ein Bereich meines Geschäfts, der seit der Machtübernahme richtig aufgeblüht ist.» [...] «Ich denke, wir haben alle ganz hübsch vom Nationalsozialismus profitiert, nicht wahr? Richtige kleine Märzgefallene.» (Kerr, 2014, p. 16)

These days I do anything from insurance investigations to guarding wedding presents to finding missing persons. Yes, that's one area of my business that's seen a real improvement since the National Socialists took power. [...] [I guess we've all done well out of National Socialism, haven't we? Proper little March Violets.] (Kerr, 1989)

Irony (frequently also self-irony), an axis of all the protagonist's statements, results from his essentially common-sense view of the world along with a strong need for social justice. This need was strongly shaken by the state system, so he was left with faith in his own sense of justice combined with faith in his own indestructibility and need for self-determination. These are the factors that influence his way of expression, thinking and feeling:

[...] Pan zaś musi być - tu udałem, że czytam jego wizytówkę - doktorem Fritzem Schemmem, germańskim adwokatem. - Słowo „germańskim” wymówiłem z naciskiem niepozbawionym ironii. Kiedy widziałem je na wizytówkach czy szyldach, zawsze budziło we mnie niechęć, podkreślało rasową nieskazitelność. 
A w tym przypadku, skoro Żydom i tak nie wolno było wykonywać zawodu prawnika, było zbędne. -- Nigdy nie określiłbym siebie mianem "germańskiego prywatnego wywiadowcy”, równie dobrze mógłbym nazywać się „wywiadowcą antysocjalistycznym”, „wywiadowcą owdowiałym” lub „wywiadowcą luterańskim". Wszystko to byłoby prawdą, choć ostatnie już niepełną, bo dawno przestałem chodzić do kościoła. (Kerr, 2014, p. 18)

[...] "and you must be -" I pretended to read his business card, "- Dr Fritz Schemm, German Lawyer." I uttered the word "German" with a deliberately sarcastic emphasis. I've always hated it on business cards and signs because of the implication of racial respectability; and even more so now that - at least as far as lawyers are concerned - it is quite redundant, since Jews are forbidden to practise law anyway. I would no more describe myself as a "German Private Investigator" than I would call myself a "Lutheran Private Investigator" or an "Antisocial Private Investigator" or a "Widowed Private Investigator", even though I am, or was at one time, all of these things (these days I'm not often seen in church). (Kerr, 1989)

This way of behaving and constructing statements seems to predestine the protagonist to be called a hero who fights against the system (theoretically an anti-hero). He sees the tragicomism of the situation and, resorting to irony, attempts to express his disapproval. Bernie Gunther says what he thinks, and the irony and cynicism in his statements become his weapon. Such verbal behaviour shows his moral backbone - in the context of the contemporary society, they meant opposition, a form of disapproval of reality, and therefore have a strongly evaluative character. In his case, irony as a linguistic means of valuation is a tool of self-defence, a mechanism supporting the protagonist in dealing with the situation, allowing him to hide his helplessness and the inability to self-determine. As social accord is prevalent in his environment (the general consent of the society to this way of functioning which he fights) his way of thinking and expressing his thoughts is a manifestation of the individual's opposition to totalitarianism - extending into every sphere of life - including language.

Bernie Gunther, as a former policeman, knows the language of criminals, uses it, and thus tries to mingle with the interlocutor, often basing his statements on the aforementioned dichotomy of us $\neq$ them. "We", i.e. the nation in the macro structure - this aspect is a frequent source of mockery - e.g. "Zatem Paul Pfarr należał do naszych czarnych aniołów!" (Kerr, 2007, p. 50) ["So Paul Pfarr was a black angel."] (Kerr, 1989)] - and "we" in the micro context - as the good, the thinking, the fighting-with-the-imposed-social- 
classification, those who are not afraid, who are similar and of convergent views. Language and irony, therefore, connect the characters, give them an illusory sense of security, and allow today's reader to observe how relationships and mutual dependencies were established at that time.

\section{The lexical image of expressing values and irony in the context of speech acts}

Obviously, a sociolinguistic analysis basis cannot do without taking lexicology into account, because as Shumarova (2004, p. 27) states:

Sociolinguistics delves into searching for correlations and dependencies between the use of a word and the social parameters of speakers, aims to establish preferences in the choice of variants and to explain similar facts. ${ }^{28}$ (after Trysińska, 2015, p. 47)

The introductory sentence, placed as the opening sentence of the novel, is an interesting example of an ironic, emotionally charged speech act, evident through an indirect speech act:

Dziwniejsze rzeczy zdarzały się już w mrocznych snach Wielkiego

Przywódcy...

Merkwürdige Dinge ereignen sich in den dunklen Träumen des Großen Verführers...

Stranger things happen in the dark dreams of the Great Persuader...

(Kerr, 1989)

The German-language version, i.e. the noun Verführer, created through affixation - by adding the word-forming suffix -er to obtain the masculine form and the prefix ver- modifying the meaning, is semantically based on the relation between the Führer - Verführer ${ }^{29}$ lexemes, on a specific play on words. Due to the fact that the phrase der Große Verführer ${ }^{30}$ contains the

\footnotetext{
28 "Socjolingwistyka zagłębia się w poszukiwaniu korelacji i zależności pomiędzy stosowaniem słowa i społecznymi parametrami mówiących, dąży do ustanowienia preferencji przy wyborze wariantów i wyjaśnienia podobnych faktów.” (za Trysińska, 2015, p. 47).

${ }^{29}$ More on the conceptualisation of the lexeme Führer as a valuating unit see: Kukowicz-Żarska (2019, pp. 114-115).

30 Interestingly, the collocation der Große Verführer also appears in German in a slightly different sense than the one proposed here, i.e. as a 'great lover of cinema', which seems to be
} 
lexeme Führer as an integral part, it becomes semantically more capacious and of strongly (here positively by definition) evaluative semantic characterization, and thus evokes wider associations than the Polish phrase Wielki Przywódca (the Great Leader). The Nazi neologism Führer served both as a title and an epithet, and, based on the fascist model, it was unequivocally associated with Hitler. It appeared in the 20s of the 20th century. The hailing of Hitler as "our Führer" by Hermann Esser during a public appearance in the Krone circus (Zirkus Krone) on July 29, 1921, on the evening of his election as chairman of the NSDAP, corresponded to the universally binding and socially accepted language usage act (cf. Schmitz-Berning, 2000, pp. 241242). In this context, and in this era, being a Great Leader is an inherent value of the system, and the use of capital letters only emphasizes this fact. Each of these speech acts is an interesting example of an indirect speech act due to the fact that when interpreting them, the context must always be taken into account - undoubtedly strange things happen, but there have been stranger situations. The ellipsis at the end of the phrases shows the author's emotional attitude to the reality described in this way, is an understatement, an announcement of something that is not to be specified or should not be stated directly.

It is not only the recognition of the sender's intentions which is a key element in the interpretation of a statement, it is also necessary to know the context and the socio-cultural situation, e.g. to decipher the following euphemisms:

pilot sportowy (Sportflieger) - sports flyer - in the sense of 'a fighter pilot undergoing secret combat training':

Oczywiście nie trzeba być detektywem, by odgadnąć, że „pilot sportowy” to jeden $\mathrm{z}$ tych ozdobnych hitlerowskich eufemizmów, oznaczający po prostu pilota przechodzącego tajne szkolenie bojowe. (Kerr, 2014, p. 12)

Natürlich brauchte man kein Detektiv zu sein, um darauf zu kommen, daß «Sportflieger» eine dieser phantasievollen Umschreibungen der Nazis war und sich auf die geheime Ausbildung von Kampffliegern bezog. (Kerr, 2007, p. 16)

reflected in the Polish term amant [suitor] or uwodziciel. [seducer] - e.g. Der Große Verführer as the German title of the film Don Juan from 1956 directed by John Berry (Pl. Miłość Don Juana). [Don Juan's Love] In this case, one can also find a certain motivation in the context of the novel: uwodziciel [the seducer] - as 'the one who seduced the nation and pulled it along, towards the ideas he professed'. 
Of course it didn't take a detective to work out that "Sports Flyer" was one of those fancy Reich euphemisms, and that this particular one related to the secret training of fighter pilots. (Kerr, 1989)

or czarne anioły (schwarze Engel) - black angels - in the sense of an 'SS member':

Zatem Paul Pfarr należał do naszych czarnych aniołów! (Kerr,

2007, p. 50)

Paul Pfarr war also ein schwarzer Engel. (Kerr, 2014, p. 55)

So Paul Pfarr was a black angel. (Kerr, 1989)

What seems interesting from the point of view of linguistic analysis is the first fragment of the novel - i.e. the first two sentences (ignoring the opening sentence discussed above) introducing the recipient to the world into which they immerse deeper and deeper as they read on:

This morning, at the corner of Friedrichstrasse and Jägerstrasse, I saw two men, SA men, unscrewing a red Der Stürmer showcase from the wall of a building. Der Stürmer is the anti-Semitic journal that's run by the Reich's leading Jewbaiter, Julius Streicher. (Kerr, 1989),

which in Polish reads similarly:

Owego ranka zobaczyłem na rogu Friedrichstrasse i Jagerstrasse, jak dwóch facetów z SA zdejmuje ze ścian budynku czerwoną gablotę "Sturmera”. „Der Sturmer” to antysemicka gazeta wydawana przez głównego żydożercę Rzeszy, Juliusa Streichera. (Kerr, 2014, p. 9).

[gloss:] That morning, on the corner of Friedrichstrasse and Jagerstrasse, I saw two guys from SA take the red Sturmer showcase off the walls of the building. "Der Sturmer" is an anti-Semitic newspaper published by the main Jew-eater of the Reich, Julius Streicher. [own translation - A.J.]

What makes one wonder is the fact that the German edition lacks a translation of one of the sentences cited above, namely the second sentence, which theoretically constitutes a speech act with an informative function, but the lexical unit with a strong negative character used here makes its expressive character clearly visible. Therefore, the passage in question in the German text reads as follows: 
Heute morgen sah ich an der Ecke Friedrichstraße und Jägerstraße zwei SA-Männer, die einen roten Schaukasten des Stürmers von der Mauer eines Gebäudes abschraubten. (Kerr, 2007, p. 13)

The second sentence, therefore, is omitted altogether from the German text perhaps by oversight - although this phrase appears at the very beginning of the novel on its first page. The absence of this sentence, which would seem crucial to the understanding of the novel, leads to a certain complication in the reception of the text, because in the context of the novel's structure, together with the last sentence of the novel it forms a kind of clamp that holds the story together:

Czerwone gabloty „Sturmera” wróciły na rogi ulic, a gazeta Streichera zionęła jeszcze większym jadem. (Kerr, 2014, p. 302)

Die roten Schaukästen des Stürmers hingen wieder an den Straßenecken, und Streichers Hetzblatt schien womöglich noch mehr zu hetzen als je zuvor. (Kerr, 2007, p. 339)

The red Der Stürmer showcases were back on the street corners and, if anything, Streicher's paper seemed more rabid than ever. (Kerr, 1989)

The above-mentioned phrase appears in the German text as the closing element of the novel, but due to the absence of the introductory sentence, its impact is diminished. Therefore, omitting this highly emotionally valuating speech act, in addition to disturbing the formal framework of the novel, leads to a reduction of its impact on the recipient.

\section{Final conclusions}

Evidently, in this paper on language of valuation, the assessment of the issues analysed in the light of universal values and historical truth must be unequivocally negative. However, since linguistic analysis comes to the fore here, in order to be credible and correspond to the assumptions made at the beginning of this paper, it is to be multidimensional and must not fail to reflect on the essence of the phenomena discussed. Due to the sensitivity of the issues discussed here, I have tried to steer clear of evaluating the linguistic phenomena in the context of their moral dimension, but only to present example speech acts, juxtapose their implementations in both languages (German and Polish), explain the contexts, the source of irony or valuation, and present a potential impact of the act on the recipient. At the same time, 
realizing that the rhetoric method discussed here is a certain form of representation of the past and memory, I undertake to treat the subject in a scientific and objective manner, and, thus, consciously move away from the assumptions of cultural memory (Erinnerungskultur) in order not to breach its guiding assumptions and principles.

\section{BIBLIOGRAPHY}

Austin, J. (1993). Mówienie i poznawanie. Rozprawy i wykłady filozoficzne (translated by Bohdan Chwedeńczuk). Warszawa: Wydawnictwo Naukowe PWN.

Grabias, S. (2019). Język w zachowaniach społecznych Podstawy socjolingwistyki i logopedii. Lublin: Wydawnictwo Uniwersytetu Marii Curie-Skłodowskiej. ISBN 978-83-227-9122-6

Drozdowicz, J. (2010). Nazistowski okultyzm a niemiecka koncepcja narodu i wspólnoty. Przegląd Religioznawczy, 1 (235), 47-57.

Garlicki, A. (25 czerwca 2009). Kryminał wpisany w historię. Polityka. Accessible online: https:/www.polityka.pl/tygodnikpolityka/kultura/ksiazki/294985,1,recenzja-ksiazkiphilip-kerr-marcowe-fiolki.read (access: 14.07.2020)

Grunberger, R. (1987). Historia społeczna Trzeciej Rzeszy. (Polish translation: Witold Kalinowski), vol. I and II. Warszawa: Państwowy Instytut Wydawniczy. ISBN: 83-06-01389-1

Kerr, P. (1989). March Violets. London: Viking (e-book).

Kerr, P. (2007). Die Berlin-Trilogie. (translated by Hans J. Schütz). Reinbek bei Hamburg: Rowohlt (Inhalt: Feuer in Berlin - Im Sog der dunklen Mächte - Alte Freunde, neue Feinde). ISBN 978-3-499-24465-0

Kerr, P. (2014). Marcowe fiołki. (translated by Ewa Fiszer). Warszawa: W.A.B. ISBN: 978-83280-0946-2

Kukowicz-Żarska, K. (2019). Zur Wirkung der Worte. Sprachliche Bewertungsmittel als Indikatoren der Wortkraft in der emotionsbezogenen NS-Sprache. Forum Filologiczne Ateneum, (1(7)2019), 105-122. https://doi.org/10.36575/2353-2912/1(7)2019.105

Kukowicz-Żarska, K. (2018). O wartościowaniu i prawdzie w języku i tekście. Język narodowego socjalizmu w perspektywie językoznawczej i socjokulturowej. Forum Filologiczne Ateneum, (1(6)2018), 61-86. https://doi.org/10.36575/2353-2912/1(6)2018.061

Lipczuk, R. (2000). O wielości i wieloznaczności terminów (na przykładzie klasyfikacji aktów mowy). Acta ac Communitas, 9, 169-176.

Schmitz-Berning, C. (2000). Vokabular des Nationalsozialismus. Berlin, New York: Walter de Gruyter.

Trysińska, M. (2015). Akty mowy jako klucz do interpretacji postaw rodzicielskich. Wychowawcze, komunikacyjne i edukacyjne aspekty filmów animowanych dla dzieci (na przykładzie filmów emitowanych w MiniMini+ i Cartoon Network). Warszawa: Wydział Polonistyki Uniwersytetu Warszawskiego.

Zdunkiewicz, D. (1993). Akty mowy. In: Bartmiński, J. (Ed.) Encyklopedia kultury polskiej XX wieku, vol. 2, Współczesny język polski (pp. 259-270). Wrocław: Wydawnictwo: "Wiedza o kulturze". 
